\title{
Pengembangan Perangkat Pembelajaran Model Inkuiri Terstruktur untuk Meningkatkan Keterampilan Komunikasi dan Kreativitas Peserta Didik Kelas V Sekolah Dasar
}

\author{
R. Bambang Nugraha*, Wahono Widodo, Nadi Suprapto \\ Program Studi Pendidikan Dasar, Pascasarjana, Universitas Negeri Surabaya \\ "Email: rnugraha.19058@mhs.unesa.ac.id \\ DOI: https://doi.org/10.33369/pendipa.6.1.162-168
}

\begin{abstract}
[The Development of Structured Inquiry Model Learning Set to Improve the Communication Skills and Creativity of Grade V Elementary School Students]. The latest science learning must contain student-centered activities so they are able to practice communication skills and creativity. This study aims to produce valid, practical, and effective structured inquiry learning sets to improve students communication skills and creativity. This research was an $R \& D$ model development research with one group pretest-posttest design and one shot case study design and tested on 20 students of class V SDN Geluran 1. Data obtained through validation, observation, questionnaires, and creativity tests. Validation was carried out by three experts and the reliability was analyzed using Alpha Cronbach. Observations were carried out by two observers. Questionnaries filled out by each student. The results of the creativity test were analyzed using the mean and $N$-Gain. The results showed that the learning set was very valid with a mean score was 91,97. The observation score shows an increase in each aspect in each meeting. Students responses ranged from $92 \%$ to $100 \%$. The average pretest result is 57 with 6 completed. The average posttest result is 85 with 20 completed. The $N$-Gain score shows 6 students in the high category and 14 students in the medium category. It can be concluded that the students communication skills and creativity can be improved by using structured inquiry learning model.
\end{abstract}

Keywords: Learning Set, Structured Inquiry, Communication Skills, Creativity.

\begin{abstract}
ABSTRAK
Pembelajaran IPA terkini harus berisikan kegiatan yang berpusat pada peserta didik sehingga mampu melatih keterampilan komunikasi dan kreativitas. Penelitian ini bertujuan menghasilkan perangkat pembelajaran model inkuiri terstruktur yang valid, praktis, dan efektif untuk meningkatkan keterampilan komunikasi dan kreativitas peserta didik. Penelitian ini merupakan penelitian pengembangan model $R \& D$ dengan one group pretest-posttest design dan one shot case study design dan diuji cobakan pada 20 peserta didik kelas V SDN Geluran I. Data diperoleh melalui validasi, observasi, angket, dan tes kreativitas. Validasi dilakukan oleh tiga orang ahli dan reliabilitasnya dianalisis menggunakan Alpha Cronbach. Observasi dilakukan oleh dua orang pengamat. Angket diisi oleh tiap peserta didik. Hasil tes kreativitas dianalisis menggunakan mean dan $N$-Gain. Hasil penelitian menunjukkan bahwa perangkat pembelajaran sangat valid dengan rerata skor 91,97. Skor observasi menunjukkan peningkatan tiap aspek di tiap pertemuan. Respon peserta didik berkisar $92 \%$ hingga 100\%. Rerata hasil pretest 57 dengan 6 yang tuntas. Rerata hasil posttest 85 dengan 20 yang tuntas. Skor $N$-Gain menunjukkan 6 peserta didik berkategori tinggi dan 14 peserta didik berkategori sedang. Dapat disimpulkan bahwa keterampilan komunikasi dan kreativitas peserta didik dapat ditingkatkan dengan menggunakan perangkat pembelajaran model inkuiri terstruktur.
\end{abstract}

Kata kunci: Perangkat Pembelajaran, Inkuiri Terstruktur, Keterampilan Komunikasi, Kreativitas. 


\section{PENDAHULUAN}

Satu diantara tujuan pendidikan antara lain agar generasi penerus mampu bersaing serta cerdas emosional dalam menguasai suatu keterampilan. Undang-undang nomor 20 tahun 2003 menyatakan bahwa pendidikan nasional merupakan pendidikan yang responsif terhadap tuntutan zaman terkini. Sains adalah tahap awal dalam mengumpulkan data alam semesta yang didapat melalui eksperimen dan pengamatan (Carin \& Sund, 1989). Dalam proses belajar, pengamatan dan eksperimen membiasakan peserta didik menggunakan nalar serta berpikir kreatif untuk menghasilkan suatu kesimpulan. Hasil pengamatan dan eksperimen yang berbeda pada tiap peserta didik membuat mereka harus mengkomunikasikan dan berdiskusi untuk mendapat suatu kesepakatan kelompok. Menurut Colin Cherry (1966), komunikasi merupakan proses memperoleh kesepakatan yang lebih baik terhadap suatu masalah penting. Keterampilan komunikasi memudahkan peserta didik menyampaikan ide dan pikirannya, berdiskusi, serta bersosialisasi dalam masyarakat.

Standar inkuiri ilmiah yang menjadi dasar dalam pembelajaran IPA membuat peserta didik terlatih berpikir kritis dan kreatif. Kreativitas menurut Baron (dalam Munandar, 2009) adalah kemampuan menciptakan sesuatu yang baru. Carl Rogers dalam Munandar (2009) menyebutkan ciri pribadi yang kreatif yaitu terbuka terhadap suatu pengalaman, mampu menilai situasi dari sudut pandang orang lain, serta senang bereksperimen.

Perangkat pembelajaran bisa berupa silabus, RPP, LKPD, instrumen evaluasi, media pembelajaran, serta buku ajar (Trianto, 2010). Menurut Kementerian Pendidikan, pengembangan perangkat merupakan suatu kegiatan yang dilakukan secara berkesinambungan. Tiap tahap pengembangan harus disertai dengan revisi. Hasil revisi kemudian diujicobakan untuk kemudian didapat hasil pengembangan. Hasil yang didapat kemudian ditelaah untuk direvisi kembali. Proses tersebut terus berulang hingga diperoleh perangkat pembelajaran yang sempurna.
Pelaksanaan pembelajaran sebenarnya sudah sesuai dengan kurikulum 2013 namun kenyataannya guru tidak mengimplementasikan pembelajaran berdasarkan kurikulum 2013. Perangkat pembelajaran yang digunakan oleh guru pun hanya mengunduh yang ada di internet. Guru tidak mengembangkan perangkat pembelajaran yang disesuaikan dengan kondisi peserta didik. Peserta didik tidak mendapat kesempatan berkomunikasi terhadap temuan atau pemikiran mereka sehingga kreativitas peserta didik menjadi rendah. Guru seharusnya mendesain pembelajaran yang memfasilitasi peserta didik untuk mencari tahu, mencoba, menyimpulkan berdasarkan pemahaman sendiri. Proses-proses dalam sains yang seharusnya dilakukan tidak tercipta selama proses pembelajaran. Kegiatan untuk membiasakan berpikir kreatif jarang dilatihkan. Peserta didik kesulitan memunculkan ide baru sehingga tidak mampu menyelesaikan masalah dalam kehidupan nyata. Usman Samatowa (2011) menyatakan bahwa sikap keingintahuan peserta didik dapat dikembangkan dengan cara selalu diberikan kesempatan mencari tahu dengan sendirinya.

National Science Educational Standart (1996) menyatakan bahwa pembelajaran IPA tidak bisa hanya langsung diberikan kepada peserta didik dalam bentuk jadi melainkan harus melalui melakukan suatu kegiatan. IPA hendaknya diajarkan menggunakan inkuiri karena mampu menumbuhkan kemampuan berpikir dan bekerja ilmiah lalu menyampaikan hasilnya. Dalam menumbuhkan keterampilan komunikasi dan kreativitas maka pembelajaran IPA tidak serta merta memberikan konsep serta produk jadi kepada peserta didik. Hanafiah (2009) mengatakan bahwa metode inkuiri merupakan pembelajaran yang menekankan kegiatan mencari serta melakukan penyelidikan sehingga suatu pengetahuan, sikap, dan keterampilan dapat ditemukan oleh peserta didik dengan sendirinya. Peserta didik diarahkan untuk menyelidiki secara mendalam sehingga memiliki kepercayaan diri dalam merumuskan penemuannya. Banchi dan Bell (2008) menyatakan bahwa inkuiri dibagi menjadi empat tingkatan berdasarkan otonomi 
yang diberikan kepada peserta didik selama proses pembelajaran. Tingkatan inkuiri dapat dilihat pada tabel 1 berikut;

Tabel 1. Tingkatan Inkuiri Banchi \& Bell

\begin{tabular}{|c|c|c|c|}
\hline $\begin{array}{l}\text { Tingkat } \\
\text { Inkuiri }\end{array}$ & Masalah & Prosedur & Solusi \\
\hline $\begin{array}{l}\text { Tingkat } 4 \\
\text { Inkuiri Terbuka }\end{array}$ & $\begin{array}{l}\text { Peserta } \\
\text { Didik }\end{array}$ & $\begin{array}{l}\text { Peserta } \\
\text { Didik }\end{array}$ & $\begin{array}{c}\text { Peserta } \\
\text { Didik }\end{array}$ \\
\hline $\begin{array}{l}\text { Tingkat } 3 \\
\text { Inkuiri } \\
\text { Terbimbing }\end{array}$ & Guru & $\begin{array}{c}\text { Peserta } \\
\text { Didik }\end{array}$ & $\begin{array}{c}\text { Peserta } \\
\text { Didik }\end{array}$ \\
\hline $\begin{array}{l}\text { Tingkat } 2 \\
\text { Inkuiri } \\
\text { Terstruktur }\end{array}$ & Guru & Guru & $\begin{array}{c}\text { Peserta } \\
\text { Didik }\end{array}$ \\
\hline $\begin{array}{l}\text { Tingkat } 1 \\
\text { Konfirmasi }\end{array}$ & Guru & Guru & Guru \\
\hline
\end{tabular}

Amri dan Ahmadi (2010) mengatakan bahwa inkuiri terstruktur adalah model pembelajaran inkuiri yang menekankan guru untuk menentukan topik, pertanyaan, bahan, serta prosedur sedangkan analisis hasil dan kesimpulan dilakukan oleh peserta didik. Inkuiri terstruktur melibatkan peserta didik untuk terlibat aktif dalam memperoleh pengetahuan melalui serangkaian kegiatan eksperimen yang dipandu suatu lembar kegiatan yang telah disiapkan guru.

Berdasarkan latar belakang tersebut, penelitian ini bertujuan mengembangkan perangkat pembelajaran model inkuiri terstruktur yang layak, praktis, dan efektif untuk meningkatkan keterampilan komunikasi dan kreativitas peserta didik kelas $\mathrm{V}$ jenjang sekolah dasar.

\section{METODE PENELITIAN}

Penelitian dilakukan di bulan MaretApril di semester 2 tahun ajaran 2020/2021 bertempat di SDN Geluran I kecamatan Taman Kabupaten Sidoarjo.

Penelitian dilakukan terhadap 20 peserta didik kelas V SDN Geluran I.

Penelitian ini menggunakan desain penelitian one group pretest-posttest design dan one shot case study design. One Group Pretest-Posttest Design digunakan untuk melihat pengaruh perangkat pembelajaran model inkuiri terstruktur terhadap kreativitas peserta didik dalam hal berpikir kreatif. One Shot Case Study Design digunakan untuk melihat peningkatan keterampilan komunikasi dan kreativitas.

Teknik pengumpulan data yang digunakan adalah validasi, observasi, angket, dan tes. Validasi digunakan untuk mengetahui kelayakan perangkat pembelajaran yang akan digunakan. Observasi digunakan untuk mengamati aktivitas guru dan peserta didik selama kegiatan pembelajaran. Observasi juga digunakan untuk mengamati keterampilan komunikasi dan kreativitas selama tiga kali pertemuan. Angket digunakan untuk mengumpulkan respon peserta didik setelah mengikuti pembelajaran menggunakan model inkuiri terstruktur. Tes digunakan untuk mengetahui peningkatan kreativitas.

Validasi dilakukan oleh tiga orang ahli. Validator memberikan checklist pada kolom skor yang sesuai kriteria di tiap indikator.

Observasi aktivitas guru dan peserta didik dilakukan oleh dua orang rekan sejawat. Observer memberikan checklist pada kolom skor yang sesuai kriteria di tiap indikator Skala penilaian validasi maupun observasi ditunjukkan tabel 2 berikut;

Tabel 2. Skala Penilaian Validasi dan Observasi (Sugiyono, 2016)

\begin{tabular}{|c|c|}
\hline Skor & Kriteria \\
\hline 1 & Tidak Baik (TB) \\
\hline 2 & Kurang Baik (KB) \\
\hline 3 & Cukup Baik (CB) \\
\hline 4 & Baik (B) \\
\hline 5 & Sangat Baik (SB) \\
\hline
\end{tabular}

Skala pengukuran angket peserta didik ditunjukkan tabel 3 berikut;

Tabel 3. Skala Penilaian Angket Peserta Didik (Riduwan, 2013)

\begin{tabular}{|c|c|}
\hline Jawaban & Skor \\
\hline Ya & 1 \\
\hline Tidak & 0 \\
\hline
\end{tabular}

Hasil validasi perangkat pembelajaran, observasi, dan angket dianalisis menggunakan rumus berikut. 


$$
p \%=\frac{\text { skor hasil pengumpulan data }}{\text { skor maksimal }} \times 100
$$

Skor rerata yang diperoleh kemudian diinterpretasi menggunakan kriteria persentase pada tabel 4 berikut;

Tabel 4. Kriteria Persentase (Riduwan, 2013)

\begin{tabular}{|c|c|}
\hline Persentase & Kategori \\
\hline $0 \%-20 \%$ & Sangat Kurang \\
\hline $21 \%-40 \%$ & Kurang \\
\hline $41 \%-60 \%$ & Cukup \\
\hline $61 \%-80 \%$ & Baik \\
\hline $81 \%-100 \%$ & Sangat Baik \\
\hline
\end{tabular}

Reliabilitas dihitung menggunakan rumus Alpha Cronbach yang terdapat dalam program data SPSS versi 22.

Hasil tes dianalisis menggunakan mean dan $N$-Gain.

\section{HASIL DAN PEMBAHASAN}

Perangkat pembelajaran sangat valid dengan rerata skor 91,97. Reliabilitas silabus 0,790. Reliabilitas RPP pertemuan 10,748 . Reliabilitas RPP pertemuan 20,674 . Reliabilitas RPP pertemuan 3 0,726. Reliabilitas LKPD pertemuan 10,682 . Reliabilitas LKPD pertemuan 20,682 . Reliabilitas LKPD pertemuan 3 0,607. Reliabilitas bahan ajar 0,974. Reliabilitas tes kreativitas 0,986.

Hasil tes kreativitas ditunjukkan pada tabel 5 berikut;

Tabel 5. Hasil Tes Kreativitas

\begin{tabular}{|c|c|c|c|c|}
\hline \multirow{2}{*}{ Nama } & \multicolumn{2}{|c|}{ Nilai } & \multirow{2}{*}{ N-Gain } & \multirow{2}{*}{ Kategori } \\
\cline { 2 - 3 } & Pre & Post & & \\
\hline A & 75 & 92 & 0.67 & Sedang \\
\hline B & 50 & 88 & 0.75 & Tinggi \\
\hline C & 50 & 88 & 0.75 & Tinggi \\
\hline D & 63 & 88 & 0.67 & Sedang \\
\hline E & 67 & 79 & 0.38 & Sedang \\
\hline F & 33 & 83 & 0.75 & Tinggi \\
\hline G & 67 & 88 & 0.63 & Sedang \\
\hline H & 25 & 79 & 0.72 & Tinggi \\
\hline I & 50 & 83 & 0.67 & Sedang \\
\hline J & 67 & 88 & 0.63 & Sedang \\
\hline K & 46 & 79 & 0.62 & Sedang \\
\hline L & 67 & 88 & 0.63 & Sedang \\
\hline M & 63 & 83 & 0.56 & Sedang \\
\hline N & 92 & 96 & 0.50 & Sedang \\
\hline O & 54 & 88 & 0.73 & Tinggi \\
\hline P & 46 & 88 & 0.77 & Tinggi \\
\hline Q & 63 & 83 & 0.56 & Sedang \\
\hline
\end{tabular}

\begin{tabular}{|c|c|c|c|c|}
\hline \multirow{2}{*}{ Nama } & \multicolumn{2}{|c|}{ Nilai } & \multirow{2}{*}{ N-Gain } & \multirow{2}{*}{ Kategori } \\
\cline { 2 - 3 } & Pre & Post & & \\
\hline $\mathrm{R}$ & 50 & 83 & 0.67 & Sedang \\
\hline $\mathrm{S}$ & 54 & 83 & 0.64 & Sedang \\
\hline $\mathrm{T}$ & 54 & 83 & 0.64 & Sedang \\
\hline
\end{tabular}

Nilai pretest berkisar antara 25 hingga 92 . Rinciannya 14 peserta didik tuntas serta 6 peserta didik tidak tuntas. Rerata nilai pretest adalah 57. Nilai posttest berkisar antara 79 hingga 96. Rinciannya 20 peserta didik tuntas. Rerata nilai posttest adalah 85.Berdasarkan tabel 5 tampak bahwa model pembelajaran inkuiri terstruktur mampu meningkatkan kreativitas peserta didik. Hal tersebut relevan dengan hasil penelitian Sandika (2018) yang menyatakan bahwa implementasi aktivitas pembelajaran berbasis inkuiri memicu seseorang menjadi aktif, mampu membangun pengetahuan serta kemampuan diri sendiri.

Peningkatan komunikasi dilihat dari observasi terhadap peserta didik saat melakukan presentasi. Observasi komunikasi dilakukan di tiap pertemuan. Aspek yang diamati hanya bahasa yang digunakan, kecepatan berbicara, intonasi, dan ketepatan waktu. Hasil observasi komunikasi tiap aspek secara rinci ditunjukkan diagram berikut ini;

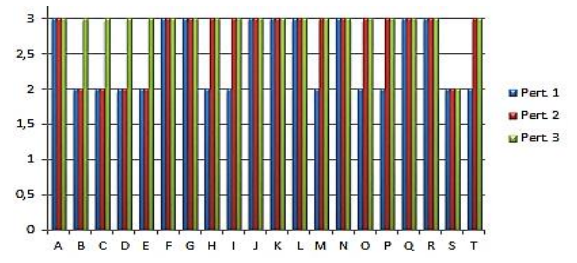

Gambar 1. Aspek Bahasa yang Digunakan

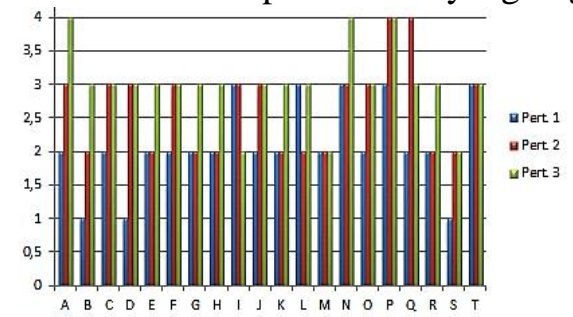

Gambar 2. Aspek Kecepatan Berbicara

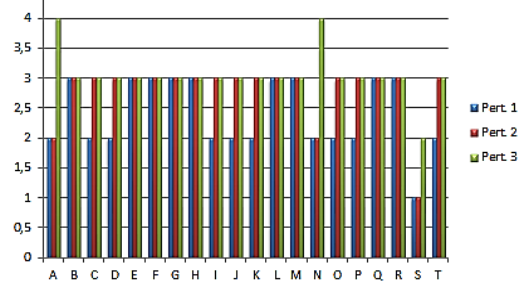

Gambar 3. Hasil Observasi Aspek Intonasi 


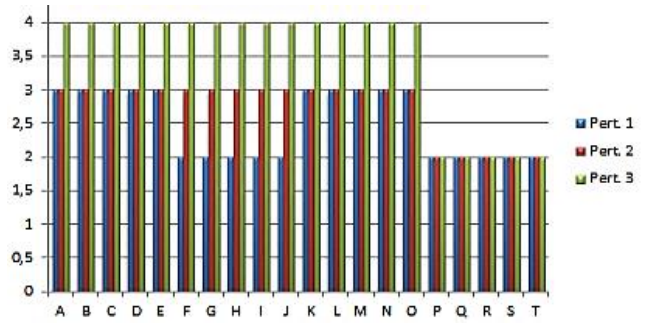

Gambar 4. Observasi Aspek Ketepatan Waktu

Gambar 1 hingga gambar 4 menunjukkan bahwa keterampilan komunikasi untuk empat aspek mengalami peningkatan tiap pertemuan. Peningkatan skor keterampilan komunikasi ditunjukkan tabel berikut;

Tabel 6. Skor Keterampilan Komunikasi

\begin{tabular}{|c|c|c|c|}
\hline \multirow{2}{*}{ Aspek } & \multicolumn{3}{|c|}{ Rerata } \\
\cline { 2 - 4 } & P1 & P2 & P3 \\
\hline $\begin{array}{c}\text { Bahasa yang } \\
\text { Digunakan }\end{array}$ & 2,45 & 2,75 & 2,95 \\
\hline $\begin{array}{c}\text { Kecepatan } \\
\text { Berbicara }\end{array}$ & 2,1 & 2,65 & 3 \\
\hline Intonasi & 2,4 & 2,8 & 3,05 \\
\hline $\begin{array}{c}\text { Ketepatan } \\
\text { Waktu }\end{array}$ & 2,45 & 2,7 & 3,4 \\
\hline
\end{tabular}

Tabel 6 menunjukkan rerata skor keterampilan komunikasi keempat aspek meningkat tiap pertemuan. Hasil tersebut relevan dengan penelitian Wildan (2019) yang menyatakan bahwa pendekatan inkuiri memudahkan peserta didik dalam berkomunikasi karena mereka mendapat pengalaman belajar secara langsung. Hal tersebut dibuktikan dengan rerata skor keterampilan komunikasi pada kelas eksperimen adalah 81,30 sedangkan rerata skor kelas kontrol adalah 65,83.

Peningkatan kreativitas dilihat dari observasi terhadap peserta didik saat melakukan presentasi. Observasi kreativitas dilakukan di tiap pertemuan. Aspek yang diamati hanya keaslian ide, fleksibilitas, kelancaran berpikir, dan elaboratif. Hasil observasi kreativitas tiap aspek secara rinci ditunjukkan diagram berikut ini;

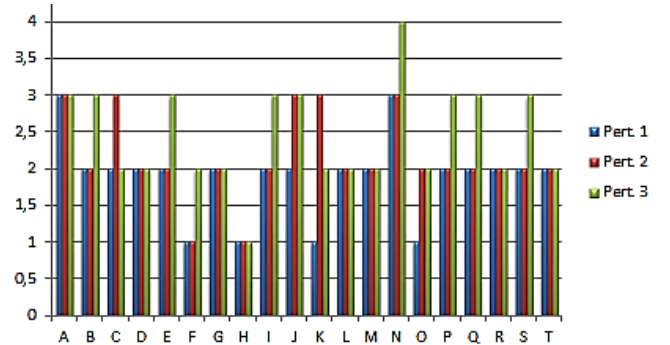

Gambar 5. Observasi Aspek Keaslian Ide

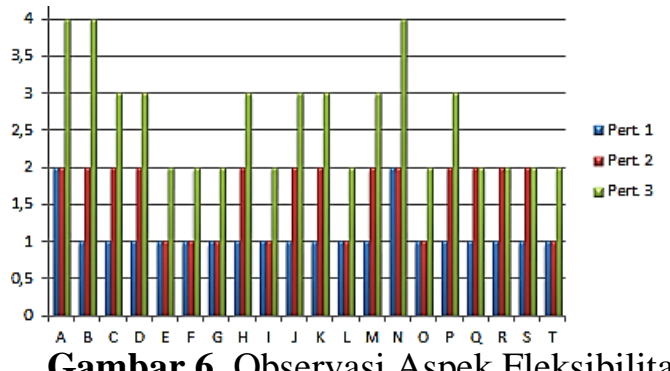

Gambar 6. Observasi Aspek Fleksibilitas

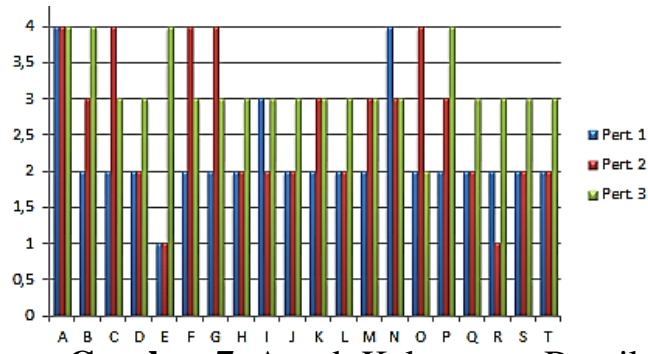

Gambar 7. Aspek Kelancaran Berpikir

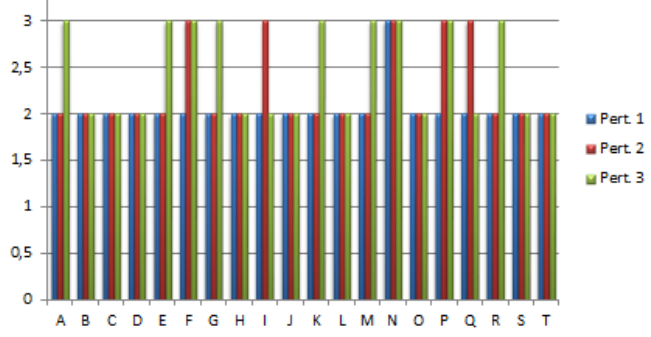

Gambar 8. Hasil Observasi Aspek Elaboratif

Berdasarkan gambar 5 hingga gambar 8 terlihat bahwa kreativitas untuk empat aspek tersebut mengalami peningkatan di tiap pertemuan. Peningkatan rerata skor kreativitas secara rinci ditunjukkan pada tabel 7. Tabel 7 menunjukkan bahwa rerata skor kreativitas untuk keempat aspek mengalami peningkatan di tiap pertemuan. Hasil rerata skor tersebut relevan dengan penelitian Kurniawan (2013) yang menyatakan bahwa pembelajaran inkuiri membuat peserta didik antusias melakukan rangkaian kegiatan menggambar media secara mandiri sehingga kreativitas peserta didik menunjukkan hasil yang bagus. 
Tabel 7. Rerata Skor Kreativitas

\begin{tabular}{|c|c|c|c|}
\hline \multirow{2}{*}{ Aspek } & \multicolumn{3}{|c|}{ Rerata } \\
\cline { 2 - 4 } Keaslian Ide & 1,9 & 2,15 & 2,45 \\
\hline Fleksibilitas & 1,1 & 1,65 & 2,65 \\
\hline $\begin{array}{c}\text { Kelancaran } \\
\text { Berpikir }\end{array}$ & 2,2 & 2,65 & 3,15 \\
\hline Elaboratif & 2,05 & 2,25 & 2,45 \\
\hline
\end{tabular}

\section{KESIMPULAN}

Berdasarkan hasil penelitian yang telah dilakukan dapat disimpulkan sebagai berikut: (1) Model pembelajaran inkuiri terstruktur dapat meningkatkan keterampilan komunikasi peserta didik kelas $\mathrm{V}$ sekolah dasar yang dibuktikan dengan peningkatan rerata skor observasi keterampilan komunikasi di tiap pertemuan. (2) Model pembelajaran inkuiri terstruktur dapat meningkatkan kreativitas peserta didik kelas $\mathrm{V}$ sekolah dasar yang dibuktikan dengan peningkatan rerata skor observasi kreativitas di tiap pertemuan. Peningkatan kreativitas juga ditinjau dari hasil tes kreativitas. Rerata skor pretest adalah 57 sedangkan rerata skor posttest adalah 85 . Peserta didik yang tuntas mengalami peningkatan dari yang semula hanya 6 peserta didik menjadi 20 peserta didik. Hasil $N$-Gain menunjukkan 14 peserta didik memperoleh kategori sedang serta 6 peserta didik memperoleh kategori tinggi.

\section{DAFTAR PUSTAKA}

Amri, S., dan Ahmadi, I.K. (2010). Proses Pembelajaran Kreatif dan Inovatif dalam Kelas. Jakarta : PT. Prestasi Pustakakarya.

Anam, Khoirul. (2015). Pembelajaran Berbasis Inkuiri : Metode dan Aplikasi. Yogyakarta : Pustaka Belajar.

Arikunto, Suharsimi. (2013). Prosedur Penelitian : Suatu Pendekatan Praktik. Jakarta : Rineka Cipta.

Astuti, Y., dan Setiawan, B. (2013). Pengembangan Lembar Kerja Siswa
Berbasis Pendekatan Inkuiri Terbimbing dalam Pembelajran Kooperatif pada Materi Kalor. Jurnal Pendidikan IPA Indonesia. Vol. 2(1) : 88-92.

Banchi, Heather., \& Bell, Randy. (2008). The Many Levels of Inquiry. Science and Children. 46 (2) : 26-29.

Carin, A.A. \& Sund, R.B. (1989). Teaching Science Through Discovery. $6^{\text {th }}$ edition. Ohio: Merill Publishing Company.

Cherry, Colin. (1966). On Human Communication: A Review, A Survey, and A Critics. Cambridge : Mass.

Effendy, Onong Uchjana. (2003). Ilmu Teori dan Filsafat Komunikasi. Bandung : PT Citra Aditya Bakti.

Hake, R.R. (1999). Analyzing Change Gain Scores. AREA-D American Education Research Association's Devision, Measurement and Research Methodology.

Hanafiah, Nanang. (2009). Konsep Strategi Pembelajaran. Bandung : Refika Aditama.

Kurniawan, A.D. (2013). Metode Inkuiri Terbimbing dalam Pembuatan Media Pembelajaran Biologi untuk Meningkatkan Pemahaman Konsep dan Kreativitas Siswa SMP. Jurnal Pendidikan IPA Indonesia. Vol. 2 (1) : 8-11.

Margunayasa, I Gede., Dantes, Nyoman., Marhaeni, A.A.I.N., Suastra, I Wayan. (2019). The Effect of Guided Inquiry Learning and Cognitive Style on Science Learning Achievement. International Journal of Instruction. Vol. 12 (1) : 737750.

Munandar, Utami. (2009) Pengembangan Kreativitas Anak Berbakat. Jakarta : Rineka Cipta.

National Research Council. (1996). National Science Education Standarts. USA : The National Academy of Sciences.

Nieveen. (2007). Formative Evaluation in Educational Design Research. London : Kluwer Academic Publisher. 
Ormanci, Ummuhan., dan Cepni, Salih. (2020). Investigating the Effects of WebBased Science Material for Guided Inquiry Approach on Information and Communication Skills of Students. Participatory Educational Research. Vol. 7(1) : 201-219.

Ratumanan, Tanwey Gerson dan Theresia Laurens. (2006). Evaluasi Hasil Belajar yang Relevan dengan Kurikulum Berbasis Kompetensi. Surabaya : Unesa University Press.

Riduwan. (2013). Skala Pengukuran Variabelvariabel Penelitian. Bandung: Alfabeta.

Samatowa, Usman. (2016). Pembelajaran IPA di Sekolah Dasar. Jakarta : PT Indeks.

Sandika, Bayu., dan Fitrihidajati, Herlina. (2018). Improving Creative Thinking Skills and Scientific Attitude through Inquiry-Based Learning in Basic Biology Lecture toward Students of Biology Education. Indonesian Journal of Biology Education. Vol. 4 No. 1 : 23-28.
Sugiyono. (2016). Metode Penelitian Pendidikan (Pendekatan Kuantitatif, Kualitatif, dan $R \& D)$ ). Bandung : Alfabeta.

Thiagarajan, Sivasailam et al. (1974). Instructional Development for Training Teachers of Exception Children. Bloomington : Indiana University.

Trianto. (2007). Mengembangkan Model Pembelajaran Tematik. Jakarta :

Trnova, Eva. (2014). IBSE and Creativity Development. Science Education International. Vol. 25 (1) : 8-18.

Wildan. (2019). A Stepwise Inquiry Approach to Improving Communication Skills and Scientific Attitudes on a Biochemistry Course. International Journal of Instruction. Vol. 12 (4) : 407-422.

Yang, Kuay-Keng., Lin, Shu-Fen., Hong, Zuway-R., Lin, Huann-shyang. (2016). Exploring the Assessment of and Relationship Between Elementary Students' Scientific Creativity and Science Inquiry. Creativity Research Journal. Vol. 28(1) : 16-23. 